\title{
Post-infectious purpura fulminans
}

\author{
*G R Sunilkumar ${ }^{1}$, C Somashekhar ${ }^{1}$, R Sujatha ${ }^{2}$ \\ Sri Lanka Journal of Child Health, 2015; 44(3): 169-170
}

(Key words: Post infectious, purpura fulminans, proteins C \& S)

\section{Introduction}

Purpura fulminans (PF) is a life threatening disorder of acute onset characterized by cutaneous haemorrhage and necrosis caused by disseminated intravascular coagulation (DIC) and dermal vascular thrombosis. There are 3 distinct categories: PF due to inherited or acquired abnormalities of protein or other coagulation systems, acute infectious PF and idiopathic $\mathrm{PF}^{1}$.

\section{Case report}

A 4 year old girl presented to the paediatric outpatient department with purpuric and necrotic skin lesions, predominantly involving upper and lower limbs, preceded by fever 15 days back. Purpura and ecchymosis appeared on the $8^{\text {th }}$ day of fever and progressed to necrotic skin lesions, associated with facial puffiness and pedal oedema. On examination, child was conscious, alert and haemodynamically stable with extensive necrotic skin lesions involving upper and lower limbs predominantly and few lesions in face and trunk (Figures $1 \& 2$ ).

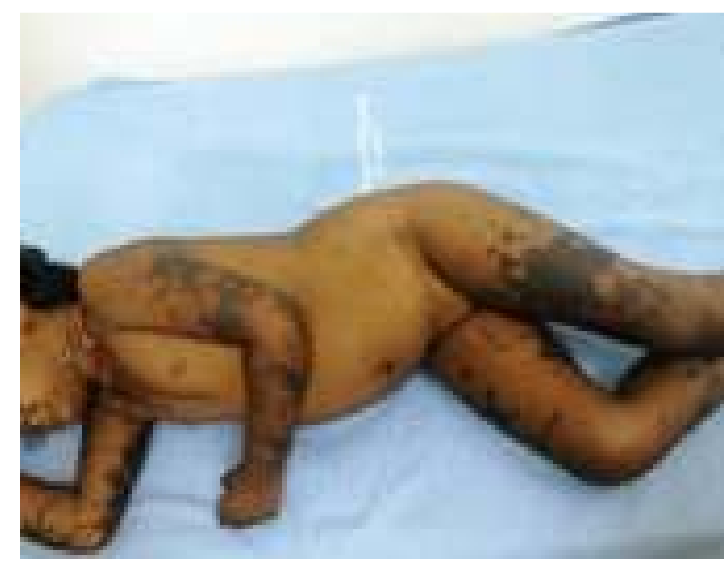

Figure 1: Purpuric lesions on limbs

\footnotetext{
${ }^{1}$ Assistant Professor, ${ }^{2}$ Professor, Department of Paediatrics, Sapthagiri Institute of Medical Sciences, Bangalore, Karnataka, India

*Correspondence: sunildoc.tmk@gmail.com
}

(Received on 21 March 2014: Accepted after revision on 30 May 2014)

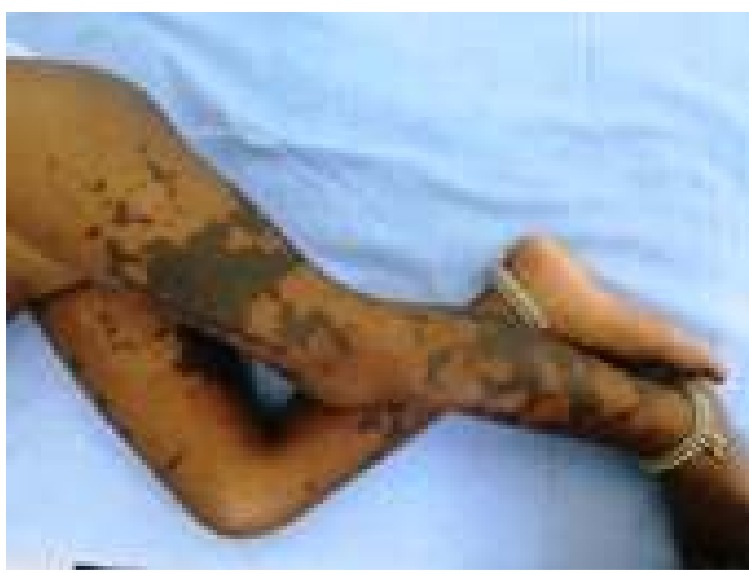

Figure 2: Purpuric lesions on lower limbs

The haemoglobin level was $8.5 \mathrm{~g} / \mathrm{dl}$. The white blood cell count was 23,300/cu mm (P73, L22, E3\%) and the platelet count $427,000 / \mathrm{cu} \mathrm{mm}$. The C-reactive protein was $39 \mathrm{mg} / \mathrm{L}$. The activated partial thromboplastin time was 34.6 seconds and the prothrombin time was 14.1 seconds. The liver function tests were normal. Blood and urine cultures showed no growth and ultrasound scan of abdomen was normal. Doppler images of upper and lower limbs were normal. Protein S level was 3\% (normal range 15-37\%), C3 complement level was $187 \mathrm{mg} / \mathrm{dl}$ (normal range $90-180 \mathrm{mg} / \mathrm{dl}$ ), anti-double stranded DNA was $26.11 \mathrm{IU} / \mathrm{ml}$ (normal <30), anti-neutrophil cytoplasmic autoantibody was 1:20 (negative) and thyroid profile was normal. We made a diagnosis of idiopathic purpura fulminans following nonspecific infection and child was managed conservatively with ampicillin and cloxacillin, packed red blood cells and fresh frozen plasma. On day 5 she showed improvement with healing of skin lesions

\section{Discussion}

Purpura fulminans (PF) is a life threatening disorder that occurs most commonly in the setting of acute severe bacterial or viral infection and as a post infectious syndrome after infections such as primary varicella and scarlet fever. Post-infectious PF usually occurs 7-10 days after onset of symptoms of acute infection. Acute infectious PF is a rapidly progressive 
disorder and its pathogenesis is described as necrotizing inflammatory lesions provoked by different bacteria and viruses. In post-infectious cases PF appears due to development of antibodies to either protein $\mathrm{C}$ or protein $\mathrm{S}$. The antibodies interfere with the function of these inhibitors of coagulation system and precipitate the microthrombi in circulation and causes varied clinical manifestations depending on the site. Transient deficiency of protein $\mathrm{C}$ and $\mathrm{S}$ has been documented in many cases ${ }^{2}$.

In a study by Levin et $\mathrm{al}^{3}$ to determine the mechanism responsible for idiopathic $\mathrm{PF}$ in five consecutive patients, in each case disease began 7-10 days after the onset of precipitating infection with rapidly progressive purpura leading to extensive area of skin necrosis. All five children had anti-protein S IgG and IgM autoantibodies and decline in protein $\mathrm{S}$ levels. Januaria $\mathrm{J}$ et $\mathrm{al}^{4}$ and Talwar et $\mathrm{al}^{5}$ have reported a case of post-infectious PF following varicella in six year old and ten year old child respectively with the same mechanism as described above. Grugery et al ${ }^{2}$ in his study of 16 patients with PF, 6 had protein $\mathrm{C}$ deficiency and 9 had protein $\mathrm{S}$ deficiency. These deficiencies except one for protein $\mathrm{S}$ were all acquired in nature.

Post-infectious PF tends to occur on the lower body especially thighs, lower legs and buttocks and phenomenon such as large vessel venous thrombosis and systemic microvascular thrombosis and multiorgan failure are uncommon. Affected children usually show acquired deficiency of protein $\mathrm{S}$ caused by cross reacting $\operatorname{IgG}$ autoantibodies that increase protein $\mathrm{S}$ clearance from the circulation. PF caused by autoantibodies to protein $\mathrm{C}$ reported rarely ${ }^{6}$. Similar findings were noted in our cases except for involvement of arms.

Post-infectious PF should be considered strongly if purpura fulminans with extensive necrotic skin lesions with or without DIC develops following nonspecific infection in an otherwise healthy child.

\section{References}

1. Nolan J, Sinclair R. Review of management of purpura fulminans and two case reports. British Journal of Anaesthesia 2001; 86: 581-6. http://dx.doi.org/10.1093/bja/86.4.581 PMid: 11573639

2. Gurgey A, Aytac S, Kanra G, Secmeer G, Ceyhan M, Altay C. Outcome of children with purpura fulminans: report on 16 patients. American Journal of Hematology 2005; 80: 2025. http://dx.doi.org/10.1002/ajh.20435 PMid: 16138355

3. Levin M, Eley BS, Louis J, Cohen H, Young L, Heyderman RS. Post-infectious purpura fulminans caused by an autoantibody directed against protein S. Journal of Pediatrics 1995; 127(3): 355-63. http://dx.doi.org/10.1016/S0022-3476(95)700633

4. Januario G, Ramroop S, Shingadia DV, Novelli V. Post-infectious purpura fulminans secondary to varicella induced protein $\mathrm{S}$ deficiency. Pediatric Infectious Disease Journal 2010; 29(10): 981-3. http://dx.doi.org/10.1097/INF.0b013e3181e5021 1

PMid: 20520582

5. Talwar A, Kumar S, Gopal MG, Nandini AS. Spectrum of purpura fulminans: report of three classical phenotypes and review of management strategies. Indian Journal of Dermatology, Venereology and Leprology 2012: 78 : 228 http://dx.doi.org/10.4103/0378-6323.93655 PMid: 22421668

6. Chalmers E, Cooper P, Forman K, Grimley C, Khair K, Minford A et al. Purpura fulminans: recognition, diagnosis and management. Archives of Disease in Childhood 2011; 96(11): 1066-71. http://dx.doi.org/10.1136/adc.2010.199919 PMid: 21233082 